\title{
Assessment of the Nutritional Status and Immunization Coverage of Anganwadi Children in Rafiq Nagar, Mumbai
}

\author{
Saiprasad Bhavsar ${ }^{1}$, Hemant Mahajan ${ }^{2, *}$, Rajan Kulkarni ${ }^{1}$ \\ ${ }^{1}$ Department of Community Medicine, TN Medical College, Mumbai, India \\ ${ }^{2}$ Department of Community Medicine, RCSM GMC Kolhapur, India
}

\begin{abstract}
India has made huge strides in the past decades in warding off the spectre of famine. The Green Revolution should have gone a long way to tackling child malnutrition, Norman Borlaug's creation of dwarf spring wheat strains in the 1960s meant that India could feed itself at last. Better farming techniques and food security policies have made mass starvation a thing of the past. Yet the problem of child malnutrition remains critical, and the reasons it deserves concerted attention are many. Besides the obvious moral obligation to protect the weakest in society, the economic cost to India is and will be staggering. The present study is carried out to assess the nutritional status and immunization coverage of children attending Anganwadi in Rafiq nagar Mumbai. A descriptive epidemiological study was conducted at Rafiq Nagar urban slum which is a field practice area of Department of Preventive and Social Medicine, TN Medical College, Mumbai, India. All children below 6 years of age attending 6 Anganwadi were included. The information was gathered by personal interview of mothers using semi-structured questionnaires. Out of 194 children 93 (47.9\%) were males. According to WHO malnutrition grading, 59.8\% children were malnourished and only 90 (46.4\%) were completely immunized. Malnutrition was prevalent in the age group of 1-2 years. Thus mother should be properly educated regarding the nutritional needs of the growing children and importance of complete immunization. Importance of exclusive breastfeeding, timely weaning, provision of proper protein rich and energy dense complementary food should be stressed.
\end{abstract}

Keywords Anganwadi, Immunization, Malnutrition, Rafiq Nagar, Urban slum

\section{Introduction}

Future of the country is determined by the growing generation of the country. It is the health status of children of any country that represents the health status of people of that country. Since this growing generation is going to be the future productive citizens, they should be healthy enough to make use of the full potential of their productive age. Scientific evidence has shown that beyond the age of 2-3 years, the effects of chronic malnutrition are irreversible. Child malnutrition is the single biggest contributor to under-five mortality due to greater susceptibility to infections and slow recovery from illness. Misconception prevalent in the present time is the unavailability of the enough food. Between 6-18 months, food availability within the household is usually not the critical factor causing malnutrition. It is more often inadequate knowledge about feeding practices that are in the best interest of the child. The denial of as little as 200-300 calories in a young child's daily

* Corresponding author:

hemant.mahajan.84@gmail.com (Hemant Mahajan)

Published online at http://journal.sapub.org/phr

Copyright (C) 2012 Scientific \& Academic Publishing. All Rights Reserved diet is what makes the difference between the normal growth and the faltering that starts the descent towards illness and death[1].

India is by no means the poorest country on earth; it doesn't have the lowest life expectancy or literacy, or the highest rate HIV/AIDS. India isn't at war, there is considerable foreign direct investment, and there is a large buffer stock of food grains. But it is far from the whole story. Mumbai, India's commercial capital is in many ways a microcosm of the country. Next to the breathtaking opulence of the down town area and the booming financial services industry, lies Asia's largest slum, the bustling Dharavi and Govandi, home to two million people - many of whom lack clean drinking water and basic sanitation.

According to the state government's data, $3.5 \%$ of Greater Mumbai's slum children under six die every year because of poor nutrition and increased risk of infections - a figure largely accepted by academics and social workers. The city has about 0.73 million slum children below the age of four (according to the government National Family Health Survey), so at least 25,550 ( $3.5 \%$ of 0.73 million) children die of malnutrition and related illnesses every year. 'Malnutrition kills 56,000 children annually in urban slums' sources according to Times of India opinion dated 10/1/11. 
About 25,000 slum children in Mumbai die of malnutrition every year, a sad fact brought to focus by the recent deaths in Mumbai's Rafiq Nagar where the study was conducted[2].

These deaths occurred in a community of rag pickers that lives off Mumbai's biggest garbage dump. If they don't spend their day sorting out and selling garbage, they can't eat. The women are anaemic; their children are born underweight, and often don't survive beyond two months. Amongst those that do, their nutritional status keeps going down because they live only on breast milk.

Hence there is an urgent need to address the serious issue of malnutrition.

\section{Materials and Methods}

The area selected for study is Rafiq Nagar, Govandi which has been declared as urban slums of Mumbai, situated in the areas besides the eastern Express Highway to Vashi. This is situated about $3 \mathrm{~km}$ from Govandi railway station and $1.5 \mathrm{~km}$ towards the north of Shivaji nagar Urban health Centre. It comes under the jurisdiction of M (east) Ward of Municipal Corporation of Greater Mumbai.

Rafiq Nagar is located under the field practice area of Department of Preventive and Social Medicine, under TN Medical College, Mumbai, India. This area has a large slum population and the parent institution provides its preventive, promotive and curative service through Urban Health Centre and Health post under Municipal Corporation of Greater Mumbai.

Rafiq Nagar is the area where all the garbage from Mumbai is dumped and called as dumping ground of Mumbai. This area has the population which has migrated from different areas of the country like West Bengal, Uttar Pradesh, Bihar, Tamil Nadu and various parts of Maharashtra. This area has predominantly Muslim population. Most of the people are rag pickers and depended on this occupation for their daily living. This area has a total population of 9500 of which total child population under 6 years of age is 1600 (Data available from Integrated Child Development Scheme Mumbai office).

Study was carried in the community of Rafiq Nagar which has a total of 12 Anganwadis. Out of those twelve Anganwadi six Anganwadi were selected by using the simple random technique using lottery method. All the children attending the Anganwadi were included into the study provided they fulfil the inclusion and exclusion criteria.

Total population of 0-6 years children in six Anganwadi was 230 out of which 194 were selected for the study as they fulfilled the study criteria. There was a loss of 36 children as the mothers were not available during the study as mothers were involved in rag picking activity during the morning hours. Still efforts were made to motivate the mothers to attend the Anganwadi centre and get enrolled into the study. When not responded by those mothers, their children were excluded from the study.
Mothers were interviewed using a preformed semi structured questionnaire and the children were examined and weight and height taken to determine the nutritional status of the child.

Collected data were entered into Microsoft excel 2007 and analyzed using appropriate tests like Pearson's Chi-square test. The confidence limit for significance was fixed at $95 \%$ level with $p$-value $<0.05$

\section{Results}

TABLE 1 shows, total 194 children were selected for the study of which 101 (52.1\%) were females and $93(47.9 \%)$ were males. According to the WHO growth card, 78 (40.20\%) were found to be of normal nutritional status whereas 116 $(59.80 \%)$ children were suffering from malnutrition. Of these 116 children $73(37.60 \%)$ children were suffering from moderate acute malnutrition (MAM) and $43(22.20 \%)$ children were suffering from severe acute malnutrition (SAM). Moderate malnutrition was more prevalent in females and severe malnutrition was more prevalent amongst the males. Out of 194 children, 111 children $(57.20 \%)$ were suffering from chronic malnutrition as they were below $5^{\text {th }}$ percentile for their height for age. Amongst these 55 (49.5\%) were females and $56(50.5 \%)$ were males. Total $84(43.30 \%)$ children had wasting as they were below $5^{\text {th }}$ percentile for weight for their height. Females had seen more to suffering from wasting disease.

TABLE 2 describes, around $82 \%$ of the total children belonged to Muslim community. When classified according to the Kuppuswamy's socio economic scale, 144 (74.2\%) children belonged to class IV and V. 109 (56.2\%) children had their family income less than Rs. 4893 per month. 30.4\% of the fathers were illiterate whereas $43.8 \%$ of the mothers had no schooling in their life. TABLE 3, 4, 5 reveal that 90 (46.4\%) children were completely immunized for their age whereas $90(46.4 \%)$ children were partially immunized for their age. $14(7.2 \%)$ children were non-immunized till the date. BCG and OPV 0 vaccine dose had the maximum coverage; but as the age increased frequency of individual vaccination decreased. Significant association was seen between immunization status and malnutrition.

TABLE 6 reveals, as the age of the children increased the nutritional status of the children went on deteriorating though nutritional status of the children had no significant association with the age of the children. Children less than 1 year age group were the least sufferer from malnutrition $(22 \%)$. As child crosses 1 year age, malnutrition rate rises sharply to $56 \%$. Similar association was seen between height for age of the child where $11 \%$ of the children less than 1 year age group were suffering from chronic malnutrition (stunting) whereas the rate of stunting rose steeply to $63 \%$ by 2 years of age and remained almost same till 6 years of age.

A significant association was noted between the age of the child and history of the child suffering from worm infestation. None of the child gave the history of suffering 
from worm infestation in below 1 year age and the percentage rises to $26 \%$ in $1-2$ years of age and $53 \%$ in above two years of age. Similarly pallor was noted in $11.1 \%$ of the children below 1 year of age and the prevalence rises to $60.8 \%$ above 1 year of age. There was no significant association between the age of the child and history of chronic diarrhoea, LRTI (lower respiratory tract infection) and admission in hospital for any reason in the past.

Significant association was noted between the age of the children and history of rashes with or without fever in children. None of the child had history of rashes below 1 year of age and the approximately $30 \%$ of the mothers in the age group of 1-3 years gave the history of rashes and $52 \%$ of the mothers of the children above 3 years gave the history of rashes over the body in the past. It cannot be conclusively proved that the children suffered from rashes were suffering from measles. Measles brings with it various other morbidities like diarrhoea and vitamin A deficiency which is responsible for malnutrition in the children. Malnutrition and morbidities play a vicious cycle role in the life of a child.

Table 1. Distribution of children according to age and nutritional grades

\begin{tabular}{|c|c|c|c|c|}
\hline Variables & & Female $(\mathrm{n}-101)$ & Male $(\mathrm{n}-93)$ & Total \\
\hline \multirow{4}{*}{ Age } & Up to 1 year & $3(3 \%)$ & $6(6.5 \%)$ & $9(4.6 \%)$ \\
\cline { 2 - 5 } & $1-2$ years & $13(12.9 \%)$ & $17(18.3 \%)$ & $30(15.5 \%)$ \\
\cline { 2 - 5 } & $2-3$ years & $24(23.8 \%)$ & $21(22.6 \%)$ & $45(23.2 \%)$ \\
\cline { 2 - 5 } & More than 3 years & $61(60.4 \%)$ & $49(52.7 \%)$ & $110(56.7 \%)$ \\
\hline \multirow{3}{*}{$\begin{array}{c}\text { ICDS grade } \\
\text { Integrated child } \\
\text { Development Service } \\
\text { Scheme grading) }\end{array}$} & Grade I & $44(43.6 \%)$ & $31(33.3 \%)$ & $75(38.7 \%)$ \\
\cline { 2 - 5 } & Grade II & $24(23.8 \%)$ & $25(26.9 \%)$ & $49(25.3 \%)$ \\
\cline { 2 - 5 } & Grade III & $8(7.9 \%)$ & $3(3.2 \%)$ & $11(5.7 \%)$ \\
\cline { 2 - 5 } & Grade IV & $0(0 \%)$ & $1(1.1 \%)$ & $1(0.5 \%)$ \\
\hline \multirow{3}{*}{ WHO grades } & Normal & $25(24.8 \%)$ & $33(35.5 \%)$ & $58(29.9 \%)$ \\
\cline { 2 - 5 } & 2-3 SD (MAM) & $42(41.6 \%)$ & $31(33.3 \%)$ & $73(37.6 \%)$ \\
\cline { 2 - 5 } & $>3$ SD (SAM) & $19(18.8 \%)$ & $24(25.8 \%)$ & $43(22.2 \%)$ \\
\hline \multirow{2}{*}{ Height for age } & Normal & $40(39.6 \%)$ & $38(40.9 \%)$ & $78(40.2 \%)$ \\
\cline { 2 - 5 } & $>$ 5th percentile & $55(54.5 \%)$ & $56(60.2 \%)$ & $111(57.2 \%)$ \\
\hline \multirow{2}{*}{ Weight for height } & 5th percentile & $46(45.5 \%)$ & $37(39.8 \%)$ & $83(42.8 \%)$ \\
\cline { 2 - 5 } & > 5th percentile & $45(44.6 \%)$ & $39(40.9 \%)$ & $84(43.3 \%)$ \\
\hline
\end{tabular}

Table 2. Distribution of children according to Religion, socioeconomic status and education of parents

\begin{tabular}{|c|c|c|}
\hline Variables & & Frequency \\
\hline \multirow{3}{*}{ Religion } & Hindu & $25(12.8 \%)$ \\
\hline & Muslim & $159(82 \%)$ \\
\hline & Buddhist & $10(5.2 \%)$ \\
\hline \multirow{5}{*}{ Socio-economic status } & Upper (Class I) & $0(0 \%)$ \\
\hline & Upper Middle (Class II) & $0(0 \%)$ \\
\hline & Lower Middle (Class III) & $50(25.8 \%)$ \\
\hline & Upper Lower (Class IV) & $143(73.7 \%)$ \\
\hline & Lower (Class V) & $1(0.5 \%)$ \\
\hline \multirow{5}{*}{ Total Family Income } & Less than 980 & $1(0.5 \%)$ \\
\hline & $980-2935$ & $15(7.7 \%)$ \\
\hline & $2936-4893$ & $93(47.9 \%)$ \\
\hline & $4894-7322$ & $78(40.2 \%)$ \\
\hline & $7323-9787$ & $7(3.6 \%)$ \\
\hline \multirow{6}{*}{ Mother's Education } & Illiterate & $85(43.8 \%)$ \\
\hline & Primary school Certificate & $44(22.7 \%)$ \\
\hline & Middle School Certificate & $19(9.8 \%)$ \\
\hline & High School Certificate & $34(17.5 \%)$ \\
\hline & Post-high School Certificate & $5(2.6 \%)$ \\
\hline & Graduate & $7(3.6 \%)$ \\
\hline \multirow{6}{*}{ Father's Education } & Illiterate & $59(30.4 \%)$ \\
\hline & Primary school Certificate & $53(27.3 \%)$ \\
\hline & Middle School Certificate & $37(19.1 \%)$ \\
\hline & High School Certificate & $26(13.4 \%)$ \\
\hline & Post-high School Certificate & $11(5.7 \%)$ \\
\hline & Graduate & $(4.1 \%)$ \\
\hline
\end{tabular}


Table 3. Immunization status of children

\begin{tabular}{|c|c|c|c|c|}
\hline \multicolumn{2}{|c|}{} & Females & Males & Total \\
\hline \multirow{3}{*}{$\begin{array}{c}\text { Immunization status at } \\
\text { present }\end{array}$} & Completely immunized & $46(45.5 \%)$ & $44(47.3 \%)$ & $90(46.4 \%)$ \\
\cline { 2 - 5 } & Partially immunized & $48(47.5 \%)$ & $42(45.2 \%)$ & $90(46.4 \%)$ \\
\cline { 2 - 5 } & Non-immunized & $7(6.9 \%)$ & $7(7.5 \%)$ & $14(7.2 \%)$ \\
\hline
\end{tabular}

Table 4. Individual vaccination status of children

\begin{tabular}{|c|c|c|c|c|c|c|}
\hline Immunization status & $\begin{array}{c}\text { BCG AND } \\
\text { OPV }\end{array}$ & $\begin{array}{c}\text { OPV, DPT, } \\
\text { HBV1 }\end{array}$ & $\begin{array}{c}\text { OPV, DPT, } \\
\text { HBV2 }\end{array}$ & $\begin{array}{c}\text { OPV, DPT, } \\
\text { HBV 3 }\end{array}$ & $\begin{array}{c}\text { OPV/ DPT } \\
\text { Booster }\end{array}$ \\
\hline Yes & $90.70 \%$ & $88.10 \%$ & $77.30 \%$ & $63.90 \%$ & $52.10 \%$ \\
\hline No & $9.30 \%$ & $11.90 \%$ & $22.70 \%$ & $36.10 \%$ & $45.40 \%$ \\
\hline
\end{tabular}

Table 5. Association of Malnutrition with sex and Immunization status

\begin{tabular}{|c|c|c|c|c|c|}
\hline & & \multicolumn{2}{|c|}{ Malnutrition } & \multirow{2}{*}{$\begin{array}{l}\text { Pearson Chi } \\
\text { Square Test }\end{array}$} & \multirow{2}{*}{ Association } \\
\hline & & Present & Absent & & \\
\hline \multirow{2}{*}{ Sex } & Male & 55 & 38 & \multirow{2}{*}{0.032} & \multirow{2}{*}{$\begin{array}{l}\mathrm{P} \text { value }-0.86 \\
\text { Non-significant }\end{array}$} \\
\hline & Female & 61 & 40 & & \\
\hline \multirow{3}{*}{ Immunization Status } & Completely immunized & 43 & 47 & \multirow{3}{*}{10.1} & \multirow{3}{*}{$\begin{array}{c}\mathrm{P} \text { value }-0.006 \\
\text { Significant }\end{array}$} \\
\hline & Partially Immunized & 63 & 27 & & \\
\hline & Not immunized & 10 & 4 & & \\
\hline
\end{tabular}

Table 6. Association of age of child and malnutrition

\begin{tabular}{|c|c|c|c|c|c|c|}
\hline & & \multicolumn{4}{|c|}{ Age } & \multirow{2}{*}{ Chi-square test } \\
\hline & & < 1 year $(\mathrm{n}-9)$ & $1-2$ yr(n-30) & $2-3$ yr(n-45) & $>3$ yr $(\mathrm{n}-110)$ & \\
\hline \multirow{2}{*}{ WHO grading } & Malnutrition & $2(22.2 \%)$ & $17(56.7 \%)$ & $29(64.4 \%)$ & $68(61.8 \%)$ & \multirow{2}{*}{$\begin{array}{c}\text { P value-0.11; } \\
\text { Non-significant }\end{array}$} \\
\hline & Normal & $7(77.8 \%)$ & $13(43.3 \%)$ & $16(35.6 \%)$ & $42(38.2 \%)$ & \\
\hline \multirow{2}{*}{$\begin{array}{l}\text { Weight for } \\
\text { height }\end{array}$} & $<5^{\text {th }}$ percentile & $6(66.7 \%)$ & $20(66.7 \%)$ & $24(53.3 \%)$ & $60(54.5 \%)$ & \multirow{2}{*}{$\begin{array}{l}\text { P value- } 0.57 ; \\
\text { Non-significant }\end{array}$} \\
\hline & $\geq 5^{\text {th }}$ percentile & $3(33.3 \%)$ & $10(33.3 \%)$ & $21(46.7 \%)$ & $50(45.5 \%)$ & \\
\hline \multirow{2}{*}{ Height for age } & $<5^{\text {th }}$ percentile & $1(1.1 \%)$ & $19(63.3 \%)$ & $25(55.6 \%)$ & $66(60 \%)$ & \multirow{2}{*}{$\begin{array}{l}\text { P value- } 0.03 ; \\
\text { Significant }\end{array}$} \\
\hline & $\geq 5^{\text {th }}$ percentile & $8(88.9 \%)$ & $11(36.7 \%)$ & $20(44.4 \%)$ & $44(40 \%)$ & \\
\hline \multirow{2}{*}{$\begin{array}{c}\text { Worm } \\
\text { infestation in } \\
\text { past }\end{array}$} & Yes & $0(0 \%)$ & $7(23.3 \%)$ & $25(55.6 \%)$ & $64(58.2 \%)$ & \multirow{2}{*}{$\begin{array}{c}\mathrm{P} \text { value }<0.01 \\
\text { Significant }\end{array}$} \\
\hline & No & $9(100 \%)$ & $23(76.7 \%)$ & $20(44.4 \%)$ & $46(41.8 \%)$ & \\
\hline \multirow{2}{*}{ Pallor } & Yes & $1(11.1 \%)$ & $8(26.7 \%)$ & $30(66.7 \%)$ & $75(68.2 \%)$ & \multirow{2}{*}{$\begin{array}{c}\mathrm{P} \text { value }<0.01 \\
\text { Significant }\end{array}$} \\
\hline & No & $8(88.9 \%)$ & $22(73.3 \%)$ & $15(33.3 \%)$ & $35(31.8 \%)$ & \\
\hline \multirow{2}{*}{$\begin{array}{c}\text { Rash with or } \\
\text { without fever in } \\
\text { past }\end{array}$} & Yes & $0(0 \%)$ & $9(30 \%)$ & $13(28.9 \%)$ & $58(52.7 \%)$ & \multirow{2}{*}{$\begin{array}{c}\mathrm{P} \text { value }<0.01 \\
\text { Significant }\end{array}$} \\
\hline & No & $9(100 \%)$ & $21(70 \%)$ & $32(71.1 \%)$ & $52(47.3 \%)$ & \\
\hline
\end{tabular}

\section{Discussion}

The present study was the community based descriptive epidemiological study carried out in Rafiq Nagar. It was conducted during the period of August 2011 to October 2011 and the sampling method adopted was simple random sampling method.

In the present study it was found that out of 194 children $58(29.90 \%)$ were having normal nutrition status while the rest $136(70.10 \%)$ children were found to be suffering from malnutrition according to ICDS grade card. Of these 136 children $75(38.70 \%)$ were suffering from grade I malnutrition $49(25.30 \%)$ were suffering from grade II malnutrition $11(5.70 \%)$ were found to be in grade III malnutrition and $1(0.50 \%)$ child was suffering from grade IV malnutrition. According to the WHO growth card 78 $(40.20 \%)$ were found to be of normal nutritional status whereas $116(59.80 \%)$ children were suffering from malnutrition. Of these 116 children 73 (37.60\%) children were suffering from moderate acute malnutrition (MAM) and $43(22.20 \%)$ children were suffering from severe acute malnutrition (SAM).

Out of 194 children 111 children (57.20\%) were suffering from chronic malnutrition as they were below $5^{\text {th }}$ percentile (less than 2 SD) for their height for age. It can be aptly said that these children were stunted and had not achieved their 
normal height for their age. 84 (43.30\%) out of 194 children were wasted as they were below $5^{\text {th }}$ percentile (less than 2 SD) for weight for their height and shows that these children had been suffering from wasting. Goel et al in their study in Rohtak found that $57.4 \%$ children were malnourished. Out of which Grade I 107(19.8\%), Grade II 137(25.4\%), Grade III $45(8.3 \%)$ \& Grade IV 21 (3.9\%)[3]. Kapil et al studied nutritional status of 486 preschool children residing in urban slums of south Delhi revealed that overall prevalence of PEM (Protein Energy Malnutrition) was found to be $81.8 \%$, while $19.11 \%, 41.4 \%, 5.7 \%$ and $0.2 \%$ of children had grades Normal, Grade I, Grade II, Grade III, and Grade IV PEM respectively[4]. Steinohff et al in their cross sectional survey of the nutritional status of 1223 preschool age children found that $45 \%$ of the children were underweight (low weight for age), 51\% were stunted (low height for age) and $21 \%$ were wasted (low weight for height) [5].

Though not significant, it was very clear that as the age of the child increased the nutritional status of the child went on deteriorating. Malnutrition status rose drastically in $2^{\text {nd }}$ year of the age where it reached to $56.70 \%, 64.40 \%$ in $2-3$ years of the age, and $61.80 \%$ in the age group of above 3 years. Insufficient duration of exclusive breastfeeding, improper weaning and complementary feeding practices, exposure to various infectious diseases like diarrhoeal and respiratory diseases may be the responsible factors for such finding. Shubhada et al in their study revealed that malnutrition was a problem that has affected $56.93 \%$ children in the age group $1-2$ yrs and $52.8 \%$ children in the age group 2-3 yrs. The prevalence of malnutrition was significantly more in 1-3 year age group[6]. Rao et al studied 845 children in the age group of 0-5 years from three slums in Pune, Maharashtra for a period of 2 years. Peak prevalence of malnutrition was observed around 18 months and shorter period (3.5 months) of exclusive breastfeeding was probably responsible[7]. Steinohff et al in their study found that $45 \%$ of the children were underweight (low weight for age), $51 \%$ were stunted (low height for age) and 21\% were wasted (low weight for height). The nature of malnutrition strongly depended on age group. Rates of stunting increased with age, reaching $63 \%$ in fifth year of life, whereas rates of wasting peaked at $36 \%$ in second year of life and declined to $14 \%$ in the fifth year[5]. Chakraborty et al in their study found that the overall occurrence of PEM in under 6 year children was observed to be $67 \%$, however it was found to be significantly higher $(80.9 \%)$ in the age group of $1-3$ years as compared to other age groups. This age group also exhibited significantly higher prevalence $(2=14.67, \mathrm{p}<0.05)$ of Grade I, II, III PEM[8].

Though the present cultural practices had always favoured males, in present study sex of the child and the nutritional status showed non-significant association. Stunting was more prevalent in males and wasting was more prevalent amongst the females. Mittal et al in their survey found lower grades of underweight and stunting (I and II) were more common among males than females $(35.29 \% \mathrm{Vs}$ $32.85 \%$ ), whereas severe grades of underweight and stunting
(III and IV) were common in females (5.71\% Vs $2.94 \%$ ). However, the results were statistically insignificant[9]. Similarly Goel et al in their study found no significant association between nutritional status and sex of the child $(p=0.928)$ [3].

Out of 194 children 90 children were completely immunized for their age whereas 90 children were partially immunized for their age. 14 children were non-immunized till the date. According to the national statistics of NFHS 3, $57.6 \%$ of the children in India in urban area are completely immunized for their age. Total children who got BCG in the urban area are $86.9 \%$, those who got three doses of polio vaccine are $83.1 \%$, total children who got three doses of DPT vaccine are $69.1 \%$ and total children age $12-23$ months who got measles vaccine are $71.8 \%$.

Of total 116 children who were suffering from malnutrition, only $43(37.1 \%)$ of the children were completely immunized for their age and $63(54.3 \%)$ were partially immunized for their age. $14(7.2 \%)$ children were non immunized out of which $10(71.4 \%)$ children suffered from some form of malnutrition and $4(28.6 \%)$ children belonged to normal nutritional status. Statistically significant relationship was seen between immunization status and malnutrition. Immunization protects the child from 6 vaccine preventable diseases namely polio, tuberculosis, diphtheria, pertusis, tetanus, and measles. Study done by Semba et al in Indonesia showed that children with complete, partial, and no immunization coverage, respectively the prevalence of severe underweight (weight-for-age $Z$ score $<-3$ ) was 5.4, 9.9 , and $12.6 \%$, severe stunting (height-for-age $Z$ score $<-3$ ) was $10.2,16.2$, and $21.5 \%$, and current diarrhoea was 3.8 , 7.3 , and $8.6 \%$. In families where the child had complete, partial, and no immunizations, the history of infant mortality was $6.4,11.4$, and $16.5 \%$, and under-five child mortality was 7.3, 13.4, and 19.2\% (both $\mathrm{p}<0.0001$ )[10]. Reddaiah et al observed significant reductions in 1-4 year old mortality due to diarrhoea and malnutrition in the study area in contrast to control area after immunization with 2 rounds of measles at the end of 2 year[11].

\section{Conclusions and Recommendations}

Out of 194 children 93 (47.9\%) were males. According to WHO malnutrition grading, $59.8 \%$ children were malnourished and only 90 (46.4\%) were completely immunized till date. Malnutrition rate was drastically increased in the age group of 2 years. Thus in order to reduce the problem of malnutrition in children mothers should be educated regarding the nutritional needs of the growing children. As the breastfeeding was seen to be significantly associated with the nutritional status of the child, the importance of exclusive breastfeeding, timely weaning, provision of proper protein rich and energy dense complementary food should be stressed. The importance of continued breastfeeding till 2 years of age should be told to the mothers. Appropriate dietary modifications have to be 
done to ensure the increased calorie \& protein intake as per the recommendations. Uses of non expensive, culturally acceptable nutritious recipes have to be promoted and demonstrated. Importance of the immunization of children should be taught to the parents. Most of the population was unaware of the programmes running against malnutrition; hence propaganda of these programmes is necessary.

Dissemination of information regarding the immunization schedule and other nutrition programs to be done with help of Anganwadi worker, CHV's (community health visitors) and community based organization.

\section{REFERENCES}

[1] A.K. Shiva Kumar 'Child malnutrition: Myths and solutions'-The Little Magazine, myth \#7. Available at: http://www.littlemag.com/hunger/shiv2.html

[2] ' 16 children in one Mumbai slum die of malnutrition'- One World South Asia, The Hindustan Times, 13 December 2010. Available at: http://southasia.oneworld.net/todaysheadlines/16-children-in -one-mumbai-slum-die-of-malnutrition

[3] Goel M.K., Mishra R., Gaur D. \& Das A. 'Nutrition surveillance in 1-6 years old children in urban slum of a city in Northern India' The International journal of epidemiology 2007; 5 (1). Available at: http://www.ispub.com/journal/the-i nternet-journal-of-epidemiology/volume-5-number-1/nutritio n-surveillance-in-1-6-years-old-children-in-urban-slums-of-a -city-in-northern-india.html

[4] Kapil U, Bali P. Nutritional status of pre-school children of urban slum communities in Delhi. Indian Pediatr 1989; 26: 338-342.

[5] Steinhoff MC, Hilder AS, Srilatha VL, Mukarji D. Prevalence of malnutrition in Indian preschool children: a survey of wasting and stunting in rural Tamil Nadu, 1983. Bulletin of World Health Organization 1986; 64(3):457-63.

[6] Avachat S., Phalke V., Phalke D. Epidemiological study of malnutrition (under nutrition) among under five children in a section of rural area. Pravara Med Rev 2009; 4(2):20-22.

[7] Rao S, Joshi SB, Kelkar RS. 'Changes in nutritional status and morbidity over time among pre-school children from slums in Pune, India' Indian Pediatrics 2000; 37:1060-71.

[8] Chakrabarty Suman, Ghosh Rohini, Bharati Premananda 'Breastfeeding Practices and Nutritional Status of Preschool Children among the Shabar Tribal Community in Orissa, India' Proceeding of National Symposium on Tribal Health 2006; 227-234.

[9] A Mittal, J Singh, SK Ahluwalia. 'Effect of Maternal Factors on Nutritional Status of 1-5-Year-Old Children in Urban Slum Population' Indian Journal of Community Medicine 2007; 32(4):264-267.

[10] Semba RD, de Pee S, Berger S, Martini E, Ricks MO, Bloem $\mathrm{ME}$ 'Malnutrition and infectious disease morbidity among children missed by the childhood immunization program in Indonesia' Southeast Asian Journal Trop Med Public Health 2007; 38(1): 120-9

[11] Zubair Kabir, Jean Long, VP Reddaiah, John Kevany, Suresh K. Kapoor 'Non-specific effect of measles vaccination on overall child mortality in an area of rural India with high vaccination coverage: a population based case-control study' Bulletin of the World Health Organization 2003;81(4): 244-250 